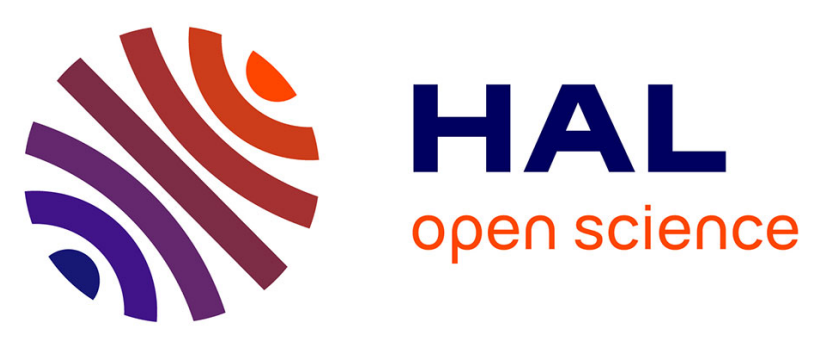

\title{
Litter N-content influences soil millipede abundance, species richness and feeding preferences in a semi-evergreen dry forest of Guadeloupe (Lesser Antilles)
}

Gladys Loranger-Merciris, Daniel Imbert, France Bernhard-Reversat, Patrick Lavelle, Jean-François Ponge

\section{To cite this version:}

Gladys Loranger-Merciris, Daniel Imbert, France Bernhard-Reversat, Patrick Lavelle, Jean-François Ponge. Litter N-content influences soil millipede abundance, species richness and feeding preferences in a semi-evergreen dry forest of Guadeloupe (Lesser Antilles). Biology and Fertility of Soils, 2008, 45

(1), pp.93-98. 10.1007/s00374-008-0321-3 . hal-00495211

\section{HAL Id: hal-00495211 \\ https://hal.science/hal-00495211}

Submitted on 25 Jun 2010

HAL is a multi-disciplinary open access archive for the deposit and dissemination of scientific research documents, whether they are published or not. The documents may come from teaching and research institutions in France or abroad, or from public or private research centers.
L'archive ouverte pluridisciplinaire HAL, est destinée au dépôt et à la diffusion de documents scientifiques de niveau recherche, publiés ou non, émanant des établissements d'enseignement et de recherche français ou étrangers, des laboratoires publics ou privés. 
Litter N-content influences soil millipede abundance, species richness and feeding preferences in a semi-evergreen dry forest of Guadeloupe (Lesser Antilles)

Gladys Loranger-Merciris ${ }^{1,2} *$. Daniel Imbert ${ }^{2}$. France Bernhard-Reversat ${ }^{1}$. Patrick Lavelle $^{1}$. Jean-François Ponge ${ }^{3}$

${ }^{1}$ UMR 137 BIOSOL, Université Pierre et Marie Curie-Paris 6 / IRD, Laboratoire d'Ecologie des Sols Tropicaux, 32 Avenue Henri Varagnat 93143 Bondy Cedex, France.

${ }^{2}$ EA 926 DYNECAR, Université des Antilles et de la Guyane, Laboratoire de Biologie et de Physiologie Végétales, BP 592, 97159 Pointe à Pitre Cedex, Guadeloupe, France.

${ }^{3}$ Muséum National d'Histoire Naturelle, CNRS UMR 7179, 4 Avenue du Petit Château 91800 Brunoy, France.

* Corresponding author: Gladys LORANGER-MERCIRIS, EA 926 DYNECAR, Université des Antilles et de la Guyane, Faculté des Sciences Exactes et Naturelles, Laboratoire de Biologie et de Physiologie Végétales, BP 592, 97159 Pointe à Pitre Cedex, Guadeloupe, France. Tel: +590 4833 28, Fax: +590 4830 65, e-mail: glorange@univ-ag.fr 


\begin{abstract}
Despite the impact of soil millipedes on litter fragmentation in tropical forests, there have been few studies dealing with factors determining their habitat preference in these ecosystems. In a natural secondary dry forest of Guadeloupe on Leptosol, two complementary studies were achieved in order to test the hypothesis that litter $\mathrm{N}$-content strongly influences millipede distribution. Millipede abundance and species richness were described in the field under two tree species, Bursera simaruba and Pisonia subcordata and were related to the chemical characteristics of their foliage. In addition, a laboratory experiment was implemented in order to assess millipede feeding preferences regarding the chemical characteristics of leaves from various species. Millipede abundance and species richness were significantly higher under $P$. subcordata than under $B$. simaruba, probably due to the higher $\mathrm{N}$ content of $P$. subcordata leaves. Moreover, millipedes fed preferentially on N-rich leaves. The present study confirms that there was a close correlation between the preferred food, its chemical composition and the local distribution of millipede populations.
\end{abstract}

Keywords Diplopoda . Dry tropical forest . Feeding preferences . Litter quality . Single tree effect 


\section{Introduction}

Soil millipedes are saprophagous invertebrates which live in litter layers or in the upper few centimetres of the soil. They mainly feed on decomposing organic material. These epigeic invertebrates greatly affect decomposition processes both directly, through fragmentation of organic material, and indirectly through control or stimulation of microbial populations and dissemination of their propagules (Petersen and Luxton 1982; Lavelle and Spain 2001).

There is currently much interest in understanding the factors that regulate the composition of soil faunal communities and its consequences for ecosystem functions (Cole et al. 2006). At a landscape level (regional mosaics of different soils), soil invertebrate communities have been shown to vary according to various habitat factors including physico-chemical characteristics of the soil (soil moisture, temperature, organic matter content, porosity, $\mathrm{pH}, \ldots$ ). Fairhurst (1974) showed that soil millipedes were often favoured by high soil $\mathrm{Ca}$ content and thus higher $\mathrm{pH}$. Ashwini and Sridhar (2006) found that millipede abundance and biomass were positively correlated with rainfall, soil moisture, soil Ca content and soil temperature in forests of Southwest India. At a local level (down to a single soil profile), soil invertebrate communities have been shown to vary according to the amount and quality of organic matter inputs (Lavelle and Spain 2001). The palatability of litter exerts some influence on invertebrate feeding activities, which might determine the patchy distribution of soil animal communities (Satchell and Lowe 1967; Swift et al. 1979; Ponge 1999). Leaf $\mathrm{N}$ content is an attractive factor for soil fauna which preferentially feed on N-rich litter (Mangenot and Toutain 1981). On the contrary, soil fauna particularly avoid litter which are rich in lignin which is particularly hard to digest in the animal gut (Palm and Rowland 1997). Soil fauna also avoid litter rich in tannin-protein complexes and 
phenols (Satchell and Lowe 1967; Harbone 1997). The trend for millipedes to feed preferentially on certain leaves has been well documented (Van der Drift 1965; Warren and Zou 2002; Ashwini and Sridhar 2005) and food preferences may be an important regulatory factor of millipede populations.

On the island of Guadeloupe, millipedes are the main saprophagous macroinvertebrates living in secondary semi-evergreen forests (Loranger 2001; Loranger et al. 2003; LorangerMerciris et al. 2007). However, factors influencing their habitat preferences are still poorly known. This is not surprising, as most taxonomic and ecological work on Myriapoda focused on temperate species (Hopkin and Read 1992). For the present study, our goal was (1) to evaluate the influence of single tree species on soil millipede abundance and species richness, and (2) to estimate the influence of litter quality on their feeding preferences in a secondary semi-evergreen forest of Guadeloupe. It has been showed that in a secondary semi-evergreen forest of Guadeloupe, there was a strong single-tree influence on humus profile development and soil macrofauna abundance (Loranger 2001; Loranger et al. 2003; Loranger-Merciris et al. 2007). Moreover, the two main plant species of this forest (Bursera simaruba and Pisonia subcordata) strongly differ in their freshly fallen leaf N-content (Loranger-Merciris et al. 2007). We hypothesised that soil millipedes may also respond to the presence of particular tree species and may differ in abundance, species assemblages and feeding preferences according to the variable resources provided by different tree species. Litter N-content would influence soil millipede communities at the local level.

\section{Materials and methods}


Study site

The study was carried out in the north-eastern part of the island of Grande-Terre, Guadeloupe archipelago (Lesser Antilles, $16^{\circ} \mathrm{N}, 61^{\circ} \mathrm{W}$ ). This area is characterised by a succession of plateaus with numerous outcrops of Pleistocene limestone bedrock. The maximum altitude is $79 \mathrm{~m}$, and the annual rainfall averages $1300 \mathrm{~mm}$, February and March being driest months with less than $60 \mathrm{~mm}$ per month on average. The mean annual temperature at the study area is $26^{\circ} \mathrm{C}$.

The study site is located in a narrow strip of a natural secondary dry forest covering a $10 \mathrm{~km}$ fault scarp which slopes up to $45 \%$. The vegetation may be characterized as neotropical semi-evergreen forest (Beard 1944). It escaped from land reclamation for agriculture due to the steep topography but is subjected to small clearcuts for charcoal production and to occasional removal of poles and stakes for building or agricultural purposes. Among the forty woody species that have been encountered on site (Imbert and Portecop 2008), the two native deciduous tree species Pisonia subcordata L. and Bursera simaruba (L.) Sarg., account for 40\% of the total basal area (Imbert and Portecop 1992). These two tree species produced $21 \%$ of the leaf litter of this forest (Loranger-Merciris, unpublished data).

The soil is a shallow calcareous Leptosol (FAO-UNESCO classification, Driessen et al. 2001). It has a silt loam texture (75\% silt in the upper $10 \mathrm{~cm}$ and $28 \%$ silt at $30-40 \mathrm{~cm}$ depth). In the top $10 \mathrm{~cm}$, the soil is rich in organic matter $(21 \% \mathrm{C})$ and has a $\mathrm{C}: \mathrm{N}$ ratio of 12.5. The $\mathrm{pH}$ (in water) is 7.5 in the top $\mathrm{cm}$ and 7.8 from 30 to $40 \mathrm{~cm}$ depth. 
Soil millipede abundance and species richness

Macroinvertebrates were sampled during the wet season under the dominant tree species mentioned above, using the modified Tropical Soil Biology and Fertility method (Anderson and Ingram 1993). Four samplings operations were achieved between 1996 and 1998. During the sampling period, the mean rainfall was $170 \mathrm{~mm}$ per month from June to November (wet season). One hundred samples were taken during the whole sampling period: in July 1996, 20 B. simaruba and 20 P. subcordata; in November 1996, 10 B. simaruba and 10 P. subcordata; in November 1997, 10 B. simaruba and 10 P. subcordata; and in June 1998, 10 B. simaruba and 10 P. subcordata. Trees from each species were randomly chosen; tree species being spread throughout the study site. Soil macroinvertebrates were collected and sorted by hand from a soil block including litter $(30 \times 30 \times 30 \mathrm{~cm})$, which was dug out with a spade then sprinkled over a plastic sheet. Millipede species (adults and juveniles) were identified at the laboratory.

Microcosm experiment: millipede feeding preferences

A choice preference experiment was conducted at the laboratory to find out feeding preferences of the three main millipede species collected in the field. Topsoil, leaf litter and millipedes were collected from the field. The soil (Leptosol from the natural secondary forest) was sieved at $2 \mathrm{~mm}$ and defaunated by drying for 5 days at $60^{\circ} \mathrm{C}$. Beside the two main tree species previously studied from the natural secondary forest, three other common tree species found on the study area were used in the experiment: Pisonia fragrans Dum.- 
Cours. (native), Tabebuia heterophylla (DC.) Britton (native) and Swietenia macrophylla King (exotic). These tree species highly contributed to litter production in this forest (Loranger-Merciris, unpublished data). A preliminary food preference experiment confirmed that freshly fallen leaves were generally avoided and that millipedes preferred more decomposed leaves (David 1986). Brown leaves of B. simaruba, P. fragrans, $P$. subcordata, S. macrophylla and T. heterophylla were taken from the OL horizon of semievergreen forest stands of Guadeloupe. The millipedes (adults) Anadenobolus monilicornis von Porat, Spilostrophus naresi Pocock and Trigoniulus corallinus Gervais were collected at the soil surface in the study site. The animals were then left starving for one day in the laboratory in Petri dishes.

Microcosms, consisting in $12 \times 10 \times 4 \mathrm{~cm}\left(480 \mathrm{~cm}^{3}\right)$ aluminium boxes, were filled with dry soil. The soil substrate was watered to field capacity at the beginning of the experiment which lasted one week. Leaves were cut into round pieces of $23 \mathrm{~mm}$ diameter. Ten pieces of leaves from two tree species ( 5 of each) were placed at the soil surface. Three millipedes were added per microcosm. A total of 10 pairs of leaf litter species were compared, with three replicates for each treatment, thus totalling 30 microcosms. After one week, the leaf surface eaten by the millipedes was measured. Each round piece of leaf was placed on a millimetre graduated paper. The leaf surface eaten by millipedes was coloured and each millimetre was counted in order to estimate litter consumption.

The contents of N, soluble phenols and fibres (cellulose, lignin) of the brown leaves of the five mentioned above tree species were analysed at the CIRAD laboratory ("Centre de Coopération Internationale en Recherches Agronomiques pour le Développement", Montpellier, France). Leaves were air-dried and milled, and total $\mathrm{N}$ content was measured using the Kjeldahl method. Methanol extractible phenols (soluble phenols sensus Palm and 
Rowland 1997) were extracted with 70\% methanol then measured colorimetrically using the Folin-Ciocalteu method (Marigo 1973). Cellulose and lignin were analysed by sequential digestion of fibres (Van Soest 1963). Samples (0.7 g milled leaves) were first extracted with neutral detergent. Lignocellulose ("acid detergent fibre" or ADF) was obtained after extraction with acid detergent. Lignin ("acid detergent lignin" or ADL) was obtained after hydrolysis of the residual with $72 \% \mathrm{H}_{2} \mathrm{SO}_{4}$. Cellulose corresponded to the difference between ADF and ADL.

Data analysis

The content (nitrogen, solubles phenols, cellulose and lignin content) of studied leaves was compared using one-way analysis of variance (ANOVA). For the field study, a preliminary ANOVA showed that there were no significant differences between the four sampling periods with regards to the millipedes collected under the same conditions. Therefore, data collected at the four sampling dates were pooled. The effect of single tree species on millipede abundance and species richness was tested using one-way ANOVA. One-way analyses of variance were also performed to assess food preferences of each millipede species in choice experiments. In order to test whether millipede feeding preferences were influenced by the chemical composition of leaves, a linear regression was performed. Data were log-transformed to normalize residuals when necessary.

\section{Results}


Soil millipede abundance and species richness

Seven millipede species were collected over the whole sampling period: Anadenobolus monilicornis von Porat, Epinannolene pittieri guadeloupensis Mauriès, Orthomorpha coarctata Saussure, Pseudospirobolellus avernus Butler, Siphonophora filiformis Mauriès, Spilostrophus naresi Pocock and Trigoniulus corallinus Gervais.

There were significantly more millipedes under $P$. subcordata $\left(59 \pm 12 \mathrm{~m}^{-2}\right)$ than under B. simaruba $\left(16 \pm 3 \mathrm{~m}^{-2}\right), \mathrm{F}_{1,91}=14.9, \mathrm{P}<0.0001$. We found significantly less millipede species under B. simaruba (4 species with two scarce species T. corallinus and S. filiformis) than under $P$. subcordata (7 species), $\mathrm{F}_{1,91}=8.4, \mathrm{P}=0.005$ (Figure 1).

Millipede feeding preferences

T. corallinus consumed significantly more leaves $\left(201 \pm 12 \mathrm{~mm}^{2}\right.$ for seven days) than $S$. naresi $\left(131 \pm 11 \mathrm{~mm}^{2}\right.$ for seven days) and A. monilicornis (82 $\pm 9 \mathrm{~mm}^{2}$ for seven days), $\mathrm{F}_{2,897}=30.9, \mathrm{P}<0.001$.

Food preferences were rather similar for the three millipede species: they preferred $P$. subcordata leaves and showed a disinclination for S. macrophylla $(\mathrm{P}<0.05$, Figure 2$)$.

Chemical analyses (Table 1) showed that fallen leaves of $T$. heterophylla and $P$. fragans had the lowest content in lignin. Leaves of $T$. heterophylla were also characterised by a higher cellulose content than other species. Fallen leaves of $P$. subcordata and $P$. fragans had a higher $\mathrm{N}$ content, twice that of other species.

Feeding preferences of the three millipede species were highly correlated with leaf $\mathrm{N}$ content $\left(\mathrm{F}_{1,3}=9.5, \mathrm{R}^{2}=0.74, \mathrm{P}=0.05\right)$. There was no significant correlation with other 
chemical parameters (data not shown).

\section{Discussion}

Millipede densities found in the semi-evergreen forest of Guadeloupe were particularly high, reaching 83 individuals. $\mathrm{m}^{-2}$. In comparison to our study, lower densities have been reported from other tropical forests: 2 millipedes. $\mathrm{m}^{-2}$ in a tropical humid forest of Ivory Coast (Aouti 1978), 77 millipedes.m ${ }^{-2}$ in a tropical humid forest of Mexico (Lavelle and Kohlmann 1984), and 27 millipedes. $\mathrm{m}^{-2}$ in a secondary forest of Yurimagas, Peruvian Amazonia (Lavelle and Pashanasi 1989).

A. monilicornis was the main millipede species in the semi-evergreen forest of the north-eastern part of Guadeloupe. This species, native of South America and known to inhabit dry soils, was previously reported for the Lesser Antilles by Mauriès (1980). Therefore, it was not surprising to see its prevalence in this dry calcareous forest. Concerning the consumption rate, $T$. corallinus consumed significantly more leaves than the two other species. This result is not surprising because $T$. corallinus is larger than the other two species ( $8 \mathrm{~cm}$ length versus 6-7 $\mathrm{cm}$ for $S$. naresi and A. monilicornis).

The higher leaf palatability of $P$. subcordata may account for the occurrence of a larger number of millipedes under this tree species, and accompanying changes in humus form (Loranger 2001; Loranger et al. 2003). Warren and Zou (2002) showed that there was an increase of millipede biomass in Leucaena leucocephala plantations in Puerto Rico due to higher substrate palatability. L. leucocephala litter may be very palatable due to its high $\mathrm{N}$ and $\mathrm{P}$ concentrations. In their study, litter quantity did not exhibit any significant correlation with soil millipede abundance, suggesting that soil millipedes were better 
associated with litter palatability rather than with litter quantity. In natural forest mosaics, preferred tree species could act as local attractors which do not contribute to regulate population size, the latter parameter being rather controlled at the ecosystem level by micro-climate, predatory activity and infectious diseases. Such a fragmented landscape with a high degree of connectedness between fragments (preferred trees) may help to maintain the high level of species richness observed in these forests (Gilbert et al. 1998).

Laboratory experiments confirmed our field observations. Millipede feeding preferences were significantly correlated with leaf $\mathrm{N}$ content, as formerly reported by Sakwa (1974). Other physical or chemical features of litter might also be involved. For example, Ashwini and Sridhar (2005) found that soil millipede abundance was negatively correlated with litter phenol content. In our study, the small range of leaves phenol content may explain the lack of correlation. However, the least palatable species S. macrophylla and $B$. simaruba contained significantly more phenols and less nitrogen than the other species.

This study corroborates the preponderant influence of single-tree species on the abundance and diversity of soil saprophagous millipedes. Moreover, we showed that the quality of organic matter was an important factor determining millipede feeding preferences and thus accounting for local variations of population abundance and species richness. Nitrogen content of litter is therefore a main ecological factor controlling the distribution of millipede populations at local level.

\section{Acknowledgments}

Thanks are due to Pr Jean-Paul Mauriès (Muséum National d'Histoire Naturelle, Paris) for 
identifying millipedes at the species level, and to Rachel Morton for her valuable help in the laboratory. The authors thank the "Office National des Forêts" (ONF) for free access to the forest plantation (Pouzzole domain). We also thank Kim Lacoste for language editing.

\section{References}

Anderson JM, Ingram JSI (1993) Tropical Soil Biology and Fertility: a handbook of methods. 2nd Edition. CAB International, Oxon

Aouti A (1978) Etude comparée des peuplements de myriapodes diplopodes d'une forêt hygrophile et d'une plantation d'Hévéa en Basse Côte d'Ivoire. Ann Univ Abidjan Ecol $11: 7-32$

Ashwini KS, Sridhar KR (2005) Leaf litter preference and conversion by a saprophagous tropical pill millipede, Arthrosphaera magna Attems. Pedobiologia 49:307-316

Ashwini KS, Sridhar KR (2006) Seasonal abundance and activity of pill millipedes (Arthrosphaera magna) in mixed plantation and semi-evergreen forest of southern India. Acta Oecol 29:27-32.

Beard JS (1944) Climax vegetation in tropical America. Ecology 25:127-158

Cole L, Bradford MA, Shaw PJA, Bardgett RD (2006) The abundance, richness and functional role of soil meso- and macrofauna in temperate grassland. A case study. Appl Soil Ecol 33:186-198

David JF (1986) Influence de la durée du séjour dans la litière des feuilles mortes de chêne (Quercus petraea Liebl.) sur la consommation par le Diplopode Cylindroiulus nitidus (Verhoeff, 1891). CR Acad Sci Paris Sci Vie 302:379-381 
Driessen P, Deckers J, Spaargaren O, Nachtergaele F (2001) Lecture notes on the major soils of the world. FAO, Rome

Fairhurst C (1974) The adaptative significance of variations in the life-cycles of Schizophiline millipedes. In: Blower JG (ed) Myriapoda. Zoological Society of London, London, pp 575-587

Gilbert F, Gonzalez A, Evans-Freke I (1998) Corridors maintain species richness in the fragmented landscapes of a microecosystem. Proc R Soc London B 265:577-582

Harbone JB (1997) Role of phenolic secondary metabolites in plants and their degradation in nature. In: Cadish G, Giller KE (eds) Driven by Nature : plant litter quality and decomposition. CAB International, London, pp 67-74

Hopkin SP, Read HJ (1992) The Biology of Millipedes. Oxford University Press, Oxford Imbert D, Portecop J (1992) La forêt tropicale semi-décidue de la Guadeloupe: structures spatiales et production de litière dans la région nord de la Grande-Terre. In: Pérennité et évolution de la flore des Caraïbes. Conservatoire des Jardins et Paysages, Terre-deHaut, Guadeloupe, pp 52-70

Imbert D, Portecop J (2008) Hurricane disturbance and forest resilience: Assessing structural vs. functional changes in a Caribbean dry forest. Forest Ecol Manag 255:3494-3501

Lavelle P, Kohlmann B (1984) Etude quantitative de la macrofaune du sol dans une forêt tropicale humide du Mexique (Bonampak, Chiapas). Pedobiologia 27:377-393

Lavelle P, Pashanasi B (1989) Soil macrofauna and land management in Peruvian Amazonia (Yurimaguas, Loreto). Pedobiologia 33:283-291

Lavelle P, Spain AV (2001) Soil Ecology. Kluwer, Amsterdam 
Loranger G (2001) Formes d'humus originales dans une forêt semi-décidue de la Guadeloupe. CR Acad Sci Paris Sci Vie 324:725-732

Loranger G, Ponge JF, Lavelle P (2003) Humus forms in two secondary semi-evergreen tropical forest stands. Eur J Soil Sci 54:17-24

Loranger-Merciris G, Imbert D, Bernhard-Reversat F, Ponge JF, Lavelle P (2007) Soil fauna abundance and diversity in a secindary semi-evergreen forest in Guadeloupe (Lesser Antilles): influence of soil type and dominant tree species. Biol Fertil Soils $44: 269-276$

Mangenot F, Toutain F (1981) Les Litières. In: Pesson, P (ed) Actualités d'écologie forestière. Gauthier-Villars, Paris, pp.3-59

Marigo G (1973) Sur une méthode de fractionnement et d'estimation des composés phénoliques chez les végétaux. Analusis 2:106-110

Mauriès JP (1980) Diplopodes Chilognates de la Guadeloupe et ses dépendances. Bull Mus Nat Hist Nat 2:1059-1111

Palm CA, Rowland AP (1997) A minimum dataset for characterization of plant quality for decomposition. In: Cadish G, Giller KE (eds) Driven by nature : plant litter quality and decomposition. CAB, London, pp 379-392

Petersen H, Luxton M (1982) A comparative analysis of soil fauna populations and their role in decomposition processes. Oikos 93:297-388

Ponge JF (1999) Interactions between earthworms, litter and trees in an old-growth beech forest. Biol Fertil Soils 29:360-370

Sakwa WN (1974) A consideration of the chemical basis of food preference in millipedes. Symp Zool Soc London 32:329-346 
Satchell JE, Lowe DG (1967) Selection of leaf litter by Lumbricus terrestris. In: Graff O, Satchell JE (eds) Progress in Soil Biology. North Holland Company, Amsterdam, pp.102-119

Swift MJ, Heal OW, Anderson JM, (1979) Decomposition in Terrestrial Ecosystems. Blackwell, Oxford

Van der Drift J (1965) The effects of animal activity in the litter layer. In Hallworth EG, Crawford DV (eds) Experimental Pedology. Butterworths, London, pp 227-235

Van Soest PJ (1963) Use of detergents in the analysis of fibrous feeds. II. A rapid method for determination of fiber and lignin. J Assoc Off Anal Chem 46:829-835

Warren W, Zou X (2002) Soil macrofauna and litter nutrients in three tropical tree plantations on a disturbed site in Puerto Rico. Forest Ecol Manag 170:161-171 
Table 1 Chemical composition of brown fallen leaves of five selected tree species collected in a natural secondary semi-evergreen forest in Guadeloupe. Values (per cent of dry matter) are averages of three replicates; standard errors are given in parentheses. For each tree species, averages with the same letter are not significantly different according to LSD test. $\mathrm{df}=4$

\begin{tabular}{lcccccc}
\hline & $\mathrm{B}$ & $\mathrm{Pf}$ & $\mathrm{P}$ & $\mathrm{S}$ & $\mathrm{T}$ & $P$ \\
\hline Total N (\%) & $0.82(0.1)^{\mathrm{c}}$ & $1.8(0.01)^{\mathrm{b}}$ & $2.2(0.03)^{\mathrm{a}}$ & $0.8(0.03)^{\mathrm{c}}$ & $0.9(0.02)^{\mathrm{c}}$ & $<0.001$ \\
Soluble phenols (\%) & $5.9(0.3)^{\mathrm{a}}$ & $0.7(0.1)^{\mathrm{c}}$ & $3.9(0.2)^{\mathrm{b}}$ & $7.5(0.2)^{\mathrm{a}}$ & $2.7(0.6)^{\mathrm{b}}$ & 0.001 \\
Cellulose (\%) & $19.9(0.2)^{\mathrm{b}}$ & $13.2(0.1)^{\mathrm{c}}$ & $18.1(0.2)^{\mathrm{b}}$ & $19.3(1.9)^{\mathrm{b}}$ & $30.6(1.7)^{\mathrm{a}}$ & 0.003 \\
Lignin (\%) & $21.7(3.9)^{\mathrm{a}}$ & $11.4(0.1)^{\mathrm{b}}$ & $28.7(0.5)^{\mathrm{a}}$ & $29(2)^{\mathrm{a}}$ & $11.7(0.1)^{\mathrm{b}}$ & 0.008 \\
\hline
\end{tabular}

$\mathrm{B}=$ Bursera simaruba $; \mathrm{Pf}=$ Pisonia fragrans $\mathrm{P}=$ Pisonia subcordata $; \mathrm{S}=$ Swietenia macrophylla; $\mathrm{T}=$ Tabebuia heterophylla. 


\section{Figure captions}

\section{Figure captions}

Figure 1 Soil millipede abundance (indivuals.m ${ }^{-2}$ ), under $B$. simaruba and $P$. subcordata canopies, in a tropical semi-evergreen forest in Guadeloupe, on Leptosol. For each millipede species, averages with the same letter are not significantly different

Figure 2 Tree species consumption $\left(\mathrm{mm}^{2}\right.$ of leaves eaten in seven days) by three millipede species (A. monilicornis, S. naresi and T. corallinus). For each millipede species, averages tree species consumption with the same letter are not significantly different 


\section{Figure 1}

Figure 1

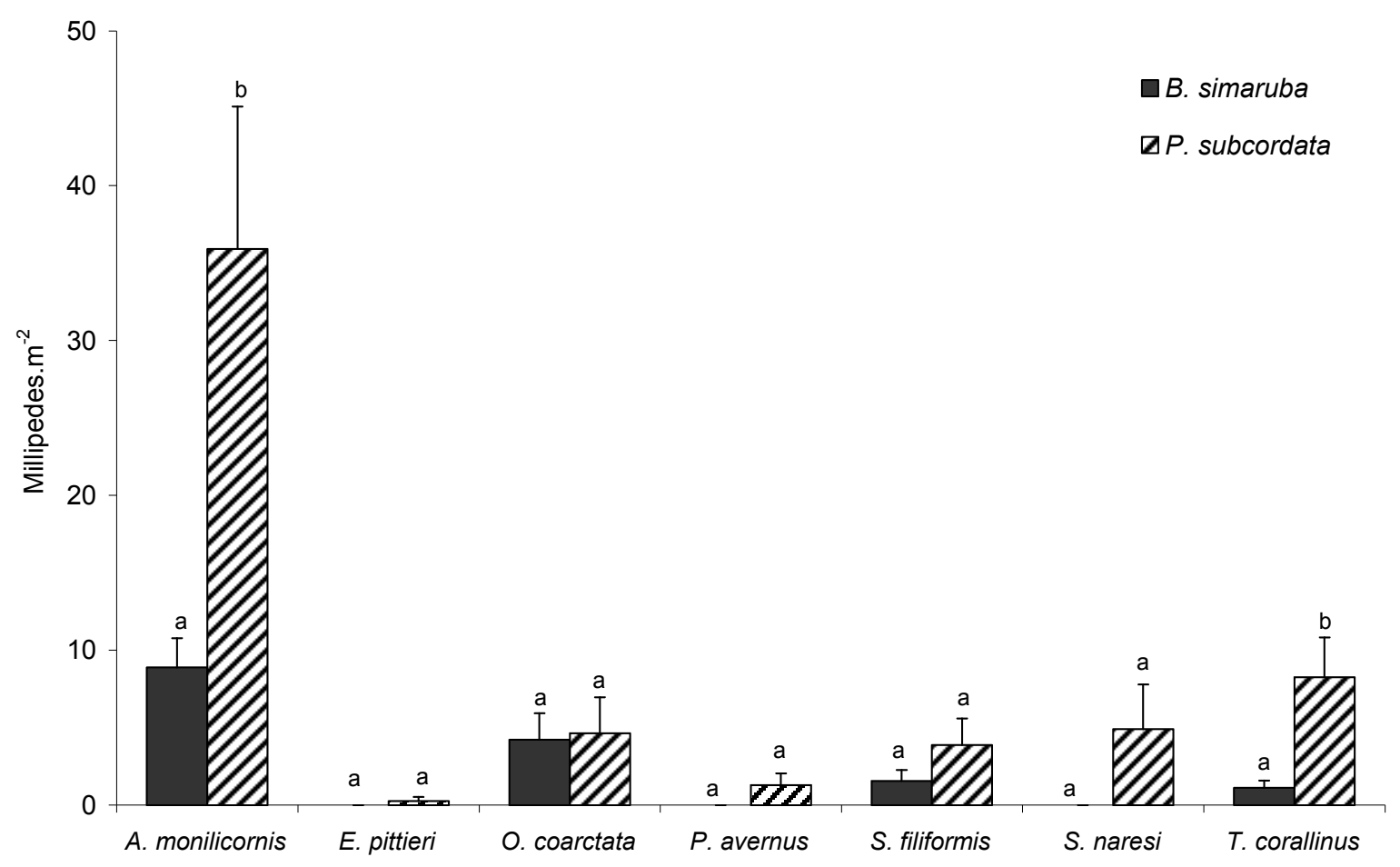


Figure 2

Figure 2

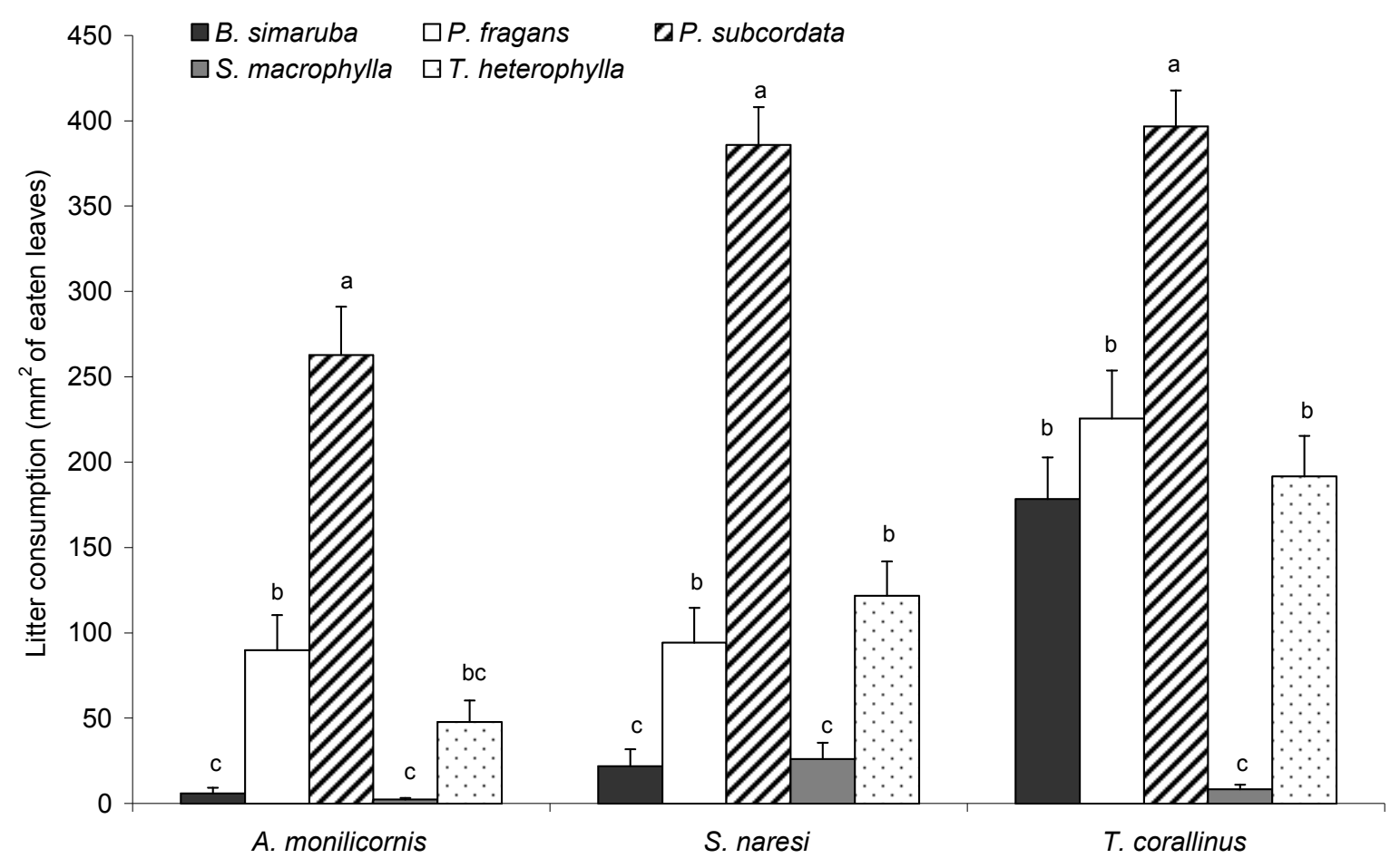

34

35

36

37

38

39

40

41

42

43

44

45

46

47

48

49

50

51

52

53

54

55

56

57

58

59

60

61

62

63

64

65 